\title{
Phytoplankton taxon-specific orthophosphate (Pi) and ATP utilization in the western subtropical North Atlantic
}

\author{
John R. Casey ${ }^{1}$, Michael W. Lomas ${ }^{1, *}$, Vanessa K. Michelou ${ }^{2}$, Sonya T. Dyhrman ${ }^{3}$, \\ Elizabeth D. Orchard ${ }^{3}$, James W. Ammerman ${ }^{4}$, Jason B. Sylvan ${ }^{5}$ \\ ${ }^{1}$ Bermuda Institute of Ocean Sciences, 17 Biological Lane, St. George's GE01, Bermuda \\ ${ }^{2}$ College of Marine and Earth Studies, University of Delaware, 700 Pilottown Road, Lewes, Delaware 19958, USA \\ ${ }^{3}$ Biology Department, Woods Hole Oceanographic Institution, 266 Woods Hole Road, Woods Hole, Massachusetts 02543, USA \\ ${ }^{4}$ School of Marine and Atmospheric Sciences, 121 Discovery Hall, Stony Brook University, Stony Brook, New York \\ 11794-5001, USA \\ ${ }^{5}$ Department of Biological Sciences, Marine Environmental Biology Section, University of Southern California, \\ 3616 Trousdale Parkway, Los Angeles, California 90089-0371, USA
}

\begin{abstract}
Utilization rates of inorganic and organic phosphorus by different picophytoplankton in the oligotrophic ocean are not well quantified. We used radioisotope tracers of orthophosphate (Pi) and the nucleic acid adenosine 5'triphosphate (ATP) to quantify P utilization into flow cytometrically sorted groups of picophytoplankton during the summer and fall of 2007 in the western Sargasso Sea. Dissolved organic phosphorus (DOP) dominated the dissolved P pool (mean \pm SD $71 \pm 56 \%$ ), while

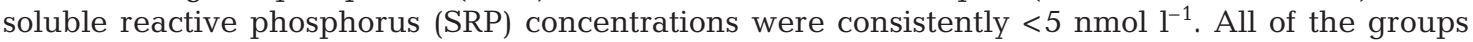
studied assimilated Pi $\left(\rho_{\mathrm{P} i}\right)$ and ATP $\left(\rho_{\mathrm{ATP}}^{*}\right)$ at significant rates. In addition, $\rho_{\mathrm{P} i}$ increased with ambient SRP concentrations, while ambient DOP concentrations had no apparent effect on either $\rho_{\text {Pi }}$ or $\rho_{\text {ATP. }}^{*}$. Consistent with community composition and contributions to autotrophic biovolume, prokaryotes were primarily responsible for P $i$ and ATP turnover. In regions where SRP was depleted to $<3 \mathrm{nmol}$ $1^{-1}$, ATP accounted for $>70 \%$ of the total P utilized. Among the individual taxa, $\rho_{\mathrm{P} i}$ and $\rho^{*}{ }_{\text {ATP }}$ increased in the order Prochlorococcus, Synechococcus, pico-, and nanoeukaryotes, when uptake was normalized to cell number, but the opposite relationship was observed when normalized to cell volume. This suggests that cyanobacteria are physiologically superior to the larger eukaryotes with respect to scavenging both Pi and ATP in the oligotrophic Sargasso Sea. A comparison of estimated C:P utilization rates with particulate $\mathrm{C}: \mathrm{P}$ ratios suggests that different phytoplankton groups may be experiencing different degrees of $\mathrm{P}$ stress in the same ambient nutrient environment. Collectively, these data suggest that the labile DOP pool, assuming that ATP is a reasonable proxy for the labile DOP pool, in the Sargasso Sea may constrain primary productivity in the absence of sufficient SRP, and that cyanobacteria have a physiological advantage for $\mathrm{P}$ utilization under these conditions.
\end{abstract}

KEY WORDS: Flow cytometry • Phosphate utilization • DOP utilization · Sargasso Sea . Picophytoplankton

Resale or republication not permitted without written consent of the publisher

\section{INTRODUCTION}

Phosphorus (P) is now widely recognized as an important limiting nutrient for autotrophic production in the world's oligotrophic oceans and large seas, due to its central role in cellular metabolism and synthesis.
Phosphate (SRP; soluble reactive phosphorus) concentrations in Sargasso Sea surface waters are low $\left(<5 \mathrm{nmol} \mathrm{l}^{-1}\right)$ during the highly stratified summer months near Bermuda and can decline even further $\left(<1 \mathrm{nmol} \mathrm{l}^{-1}\right)$ as one transects southward through the North Atlantic (Wu et al. 2000, Cavender-Bares et al. 
2001). These low concentrations have been suggested to limit microbial metabolism in the subtropical North Atlantic (Ammerman et al. 2003). Throughout most of the year in the Sargasso Sea, the majority (>80\%) of total dissolved phosphorus (TDP) exists as dissolved organic phosphorus (DOP) (Ammerman et al. 2003, M. W. Lomas et al. unpubl. data). Thus, in the absence of sufficient SRP, phytoplankton may assimilate substantial quantities of biologically labile DOP to satisfy cellular $\mathrm{P}$ quotas and support primary production. Indeed, Mather et al. (2008) inferred enhanced DOP utilization in the subtropical North Atlantic, relative to the subtropical South Atlantic (where SRP concentrations are 1 to 2 orders of magnitude higher), based upon significantly lower DOP concentrations and elevated alkaline phosphatase activities (APA), the enzyme that hydrolyzes DOP into bioavailable SRP. In fact, Mather et al. (2008) estimate 12 to $30 \%$ of autotrophic P demand in the subtropical North Atlantic gyre is met by DOP utilization. Furthermore, within the subtropical North Atlantic gyre, there is a strong gradient of decreasing DOP concentrations from east to west; by inference, the highest APA would be found in the western subtropical North Atlantic where the current study was conducted.

Currently, APA-based estimates of DOP utilization are common, but caution must be taken when evaluating this relationship as there are several important caveats. First, an APA-based estimate would only reflect the APase hydrolysable P pool and not the total biologically available DOP pool; the APase hydrolysable pool comprised between 10 and $50 \%$ of the DOP (Taft et al. 1977, Kobori \& Taga 1979) in Chesapeake Bay, USA, and Sagami Bay, Japan. In many regions of the global ocean, phosphate esters, the substrate of APase, are consistently $\sim 75 \%$ of the DOP pool based upon functional group NMR (nuclear magnetic resonance) analysis (Kolowith et al. 2001). Second, APA assays are often conducted at saturating substrate additions and must be corrected to in situ rates using kinetics curves (Ammerman \& Glover 2000) or tracer level studies, both of which are not commonly done. Lastly, APase is an inducible enzyme and has been shown to be part of the general SRP-stress response mechanism in field assemblages and cultures of Prochlorococcus (Moore et al. 2005, Martiny et al. 2006), Synechococcus (Ikeya et al. 1997, Donald et al. 2001, Moore et al. 2005, Bouman et al. 2006), Trichodesmium (Dyhrman et al. 2002, Fu et al. 2005), dinoflagellates, and diatoms (Dyhrman \& Palenik 1999, Lomas et al. 2004, Dyhrman \& Ruttenberg 2006). Furthermore, studies have shown that there can be substantial intra-group variability, particularly in Prochlorococcus, the most abundant autotroph in the Sargasso Sea. For example, high-light ecotypes MED4 and MIT9312 both have an inducible APase, but vary in the magnitude of induction, while low-light ecotypes MIT9313 and SS120 lack a recognizable APase gene (phoA), and actually down regulate APase under $\mathrm{P}$ stress (Moore et al. 2005). Moreover, Martiny and colleagues (2006, 2009) have hypothesized that ambient SRP concentrations $>100 \mathrm{nmol} \mathrm{l}^{-1}$ lead to the selective loss of P-stress response genes in Prochlorococcus lineages.

A more direct approach to $\mathrm{P}$ utilization measurements is necessary to avoid some of the problems in interpreting enzyme activities. One such approach is the combination of flow cytometric sorting and radiosolisotope tracers, which has been used to study phosphate (Pi) utilization (Zubkov et al. 2007, Larsen et al. 2008). An important question is what to use as a model organic P molecule. One such nuclease-, nucleotidase-, and APase-hydolyzable nucleic acid is adenosine 5 'triphosphate (ATP) and may serve as a model DOP molecule for utilization rate measurements. ATP is the common energy currency for cells and is released primarily from cell lysis and sloppy feeding (Azam \& Hodson 1977). Furthermore, Moore et al. (2005) found that 7 of 8 studied strains of Prochlorococcus and Synechococcus grew at near maximal rates on ATP as the sole P source in culture. We used this flow cytometric sorting/radioisotope technique to test the hypothesis that distinct phytoplankton groups, e.g. Prochlorococcus, Synechococcus, pico-, and nanoeukaryotes, utilize $\mathrm{P}$ substrates (Pi and ATP) at different rates. We collected environmental samples from the western Sargasso Sea in June and October of 2007 and used ${ }^{33} \mathrm{P}-$ labeled orthophosphate and alpha-labeled adenosine- $5^{\prime}$-triphosphate $\left(\alpha-\mathrm{AT}^{33} \mathrm{P}\right)$ as a model DOP radioisotope tracer to directly quantify $\mathrm{P}$ utilization in the major groups of picophytoplankton.

\section{MATERIALS AND METHODS}

Sample collection and $\mathbf{P}$ analysis. Environmental samples were collected from cruises in the North Atlantic subtropical gyre during June (X0705) and October (BVal39) of 2007. Transects from Bermuda extended as far north as $38^{\circ} \mathrm{N}$ and as far south as $21^{\circ} \mathrm{N}$ (Fig. 1, Table 1). Water for taxon-specific experiments was collected from $5 \mathrm{~m}, 40 \mathrm{~m}$, and the deep chlorophyll maximum (DCM; ranging from 80 to $120 \mathrm{~m}$ ) in acidcleaned Niskin bottles, and kept in subdued lighting until incubation. Whole microbial community utilization rates, $\mathrm{P}$ pool concentrations (SRP, TDP, and particulate phosphorus [PP]), and samples for flow cytometric picoplankton analysis were collected from 0 to $250 \mathrm{~m}$. SRP, TDP, and PP were processed according to the MAGIC-SRP (Karl \& Tien 1992), persulfate oxidation (Ridal \& Moore 1990), and ash hydrolysis 


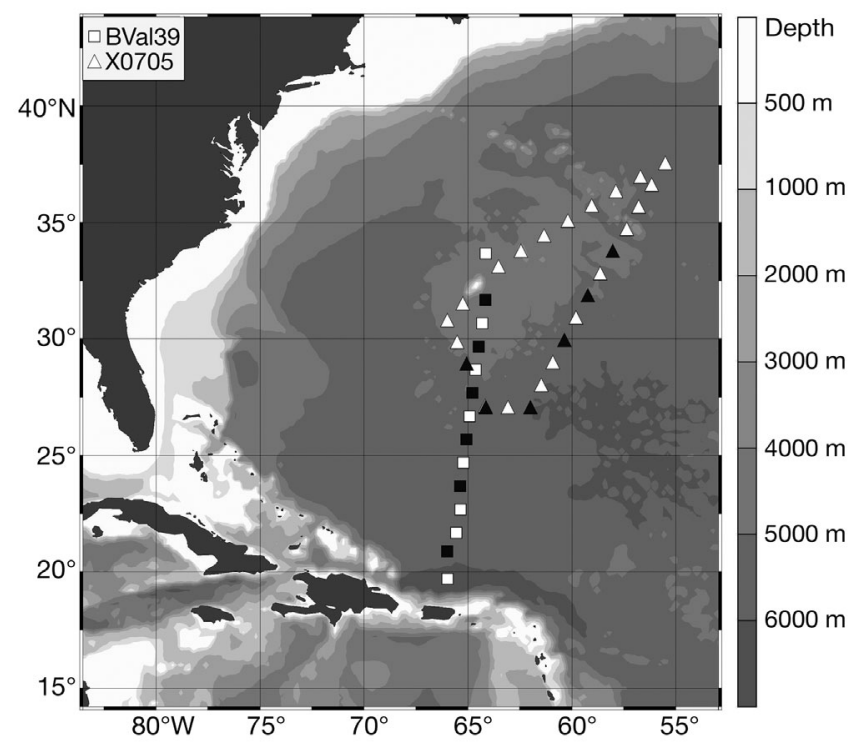

Fig. 1. The Sargasso Sea region highlighting the locations of all sampling stations considered during Cruise X0705 (triangles: June 2007) and Cruise BVal39 (squares: October 2007). Stations where taxon-specific measurements of $\mathrm{P}$ utilization were conducted are presented by the corresponding filled symbols for each cruise

(Solorzano \& Sharp 1980) methods, respectively. Any additional ancillary measurements presented in the present paper were collected and processed according to the Bermuda Atlantic Time-Series Study (BATS) protocols (Knap et al. 1997).

Radioisotope incubations. Duplicate aliquots of seawater, $10 \mathrm{ml}$, were amended with $0.15 \mu \mathrm{Ci}$ additions of $\mathrm{H}_{3}{ }^{33} \mathrm{PO}_{4}$ (40 to $60 \mathrm{Ci} \mathrm{mmol}^{-1}$; $\sim 0.3 \mathrm{nmol} \mathrm{l}^{-1} \mathrm{P}$ added; Perkin Elmer Life and Analytical Sciences) and $\alpha$ $\mathrm{AT}^{33} \mathrm{P}\left(3000 \mathrm{Ci} \mathrm{mmol}^{-1} ; 0.005 \mathrm{nmol} \mathrm{l}^{-1} \mathrm{P}\right.$ added; Perkin
Elmer Life and Analytical Sciences). ATP is relatively stable at neutral $\mathrm{pH}$. However, in seawater $(\mathrm{pH} 7.9$ to 8.0), non-biological hydrolysis of the $\gamma$-Pi happens rapidly. Therefore, to avoid issues of potential overestimation of ATP utilization, we specifically used an ATP substrate in which the $\alpha-P i$ was labeled, so that ATP utilization rates presented are more representative of biological hydrolysis. This is an important distinction as Zubkov et al. (2007), to whom we compare our data, used $\gamma-A^{33}$ P. Samples were incubated for 30 to $60 \mathrm{~min}$ in subdued lighting $\left(<20 \mu \mathrm{mol}\right.$ photons $\left.\mathrm{m}^{-2} \mathrm{~s}^{-1}\right)$ at $\sim 23^{\circ} \mathrm{C}$, which was within $\sim 3^{\circ} \mathrm{C}$ of the coolest/ warmest in situ temperatures. The duration of each incubation varied depending on the turnover time of the added isotope to keep utilization of added tracer to $<25 \%$ of the amount added. Incubations were terminated by the addition of paraformaldehyde $(0.5 \%$ final concentration). At each station, duplicate killed control incubations were conducted. Killed controls were amended with paraformaldehyde $(0.5 \%$ final concentration) for $30 \mathrm{~min}$ prior to the addition of isotopic tracer. Postincubation, all samples were stored in the dark at $4^{\circ} \mathrm{C}$ until analysis. It is recognized that fixation of the cells prior to analysis may lead to some leakage of the isotope from the cells (Larsen et al. 2008). This has been tested several times during the course of sampling efforts, and we have found that $25 \pm 5 \%$ of the isotope in $\mathrm{P} i$ incubations leaks from the cells within $24 \mathrm{~h}$; this value is comparable to the results of Larsen et al. (2008), who found $22 \%$ leakage under similar conditions. Leakage from cells in ATP incubations is lower at $13 \pm 7 \%$ within $24 \mathrm{~h}$. Utilization rates presented in this manuscript have not been corrected for this leakage.

Flow cytometry analysis. Samples for picoplankton enumeration by flow cytometry were collected from 0 to $250 \mathrm{~m}$ and fixed with paraformaldehyde $(0.5 \%$ final

Table 1. Summary for station locations during each cruise where ${ }^{33} \mathrm{P}$ taxon-specific utilization measurements were made in surface waters $(\sim 5 \mathrm{~m})$ and at the depth of the deep chlorophyll maximum (DCM). Chl a: chlorophyll $a_{\text {; }}$ SRP: soluble reactive phosphorus; DOP: dissolved organic phosphorus; APA: alkaline phosphatase activity; ND: no data

\begin{tabular}{|c|c|c|c|c|c|c|c|c|c|c|c|c|}
\hline \multirow[t]{2}{*}{ Cruise } & \multirow[t]{2}{*}{ Station } & \multirow{2}{*}{$\begin{array}{c}\text { Latitude } \\
\left({ }^{\circ} \mathrm{N}\right)\end{array}$} & \multirow{2}{*}{$\begin{array}{l}\text { Longitude } \\
\left({ }^{\circ} \mathrm{W}\right)\end{array}$} & \multirow{2}{*}{$\begin{array}{c}\mathrm{DCM} \\
(\mathrm{m})\end{array}$} & \multicolumn{2}{|c|}{$\mathrm{Chl} \mathrm{a}\left(\mathrm{ng} \mathrm{l}^{-1}\right)$} & \multicolumn{2}{|c|}{$\mathrm{SRP}\left(\mathrm{nmol} \mathrm{l} \mathrm{l}^{-1}\right)$} & \multicolumn{2}{|c|}{ DOP (nmol l-1) } & \multicolumn{2}{|c|}{ APA $\left(\mathrm{nmol} \mathrm{l}^{-1} \mathrm{~h}^{-1}\right)$} \\
\hline & & & & & Surface & DCM & Surface & $\mathrm{DCM}$ & Surface & DCM & Surface & $\mathrm{DCM}$ \\
\hline \multirow[t]{6}{*}{ X0705 } & 12 & 33.43 & 65.80 & 60 & 130 & 455 & 5.3 & 6.0 & 106.5 & 118.9 & ND & ND \\
\hline & 14 & 31.49 & 59.13 & 100 & 38 & 234 & 1.7 & 2.5 & 50.8 & 100.6 & ND & ND \\
\hline & 16 & 29.54 & 60.22 & 100 & 33 & 243 & $<1$ & 6.5 & 48.2 & 47.8 & ND & ND \\
\hline & 19 & 27.00 & 61.59 & 120 & 32 & 274 & $<1$ & 13.4 & 10.0 & 61.3 & ND & ND \\
\hline & 21 & 27.00 & 64.09 & 120 & 24 & 126 & 6.0 & 14.8 & 43.0 & ND & ND & ND \\
\hline & 23 & 28.53 & 65.04 & 100 & 55 & 250 & $<1$ & 5.5 & 72.0 & 77.9 & ND & ND \\
\hline \multirow[t]{6}{*}{ BVal39 } & 2 & 31.40 & 64.10 & 95 & 53 & 365 & $<1$ & 12.8 & 92.9 & 92.7 & 0.9 & 0.7 \\
\hline & 4 & 29.40 & 64.28 & 100 & 39 & 175 & 1.1 & $<1$ & 99.8 & 125.1 & 1.8 & 7.5 \\
\hline & 6 & 27.40 & 64.46 & 100 & 47 & 151 & 1.2 & 9.1 & 61.5 & 75.4 & 8.7 & 27.1 \\
\hline & 8 & 25.40 & 65.04 & 100 & 37 & 191 & 7.1 & 6.7 & 80.2 & 62.6 & 8.1 & 9.1 \\
\hline & 10 & 23.40 & 65.22 & 100 & 73 & 163 & 3.9 & 2.9 & 105.8 & 76.2 & 3.2 & 26.8 \\
\hline & 12 & 21.40 & 65.33 & 80 & 62 & 206 & 1.4 & 2.7 & 74.2 & 78.8 & 11.7 & 12.1 \\
\hline
\end{tabular}


concentration) at $4^{\circ} \mathrm{C}$ for from 2 to $6 \mathrm{~h}$ before being flash frozen in liquid nitrogen. Samples were sorted or analyzed on a Becton Dickenson (formerly Cytopeia) high speed jet-in-air InFlux cell sorter at an average flow rate of $40 \mu \mathrm{min}^{-1}$. Samples were sorted or analyzed for the cyanobacterial populations Prochlorococcus and Synechococcus, and 2 eukaryotic algae size fractions (picoeukaryotes $<3 \mu \mathrm{m}$; nanoeukaryotes $>3 \mu \mathrm{m}$ ). After exclusion of laser noise gated on pulse width and forward scatter (FSC), autotrophic cyanobacterial cells were discriminated by chlorophyll (to separate autotrophs from similarly sized heterotrophs) and phycoerythrin (PE) fluorescence (to separate Prochlorococcus from Synechococcus), as well as FSC, in accordance with methods used by Zubkov et al. (2007). Autotrophs excluded from the cyanobacteria gates were assumed to be eukaryotes. Within the eukaryotes positive gate, pico- and nanoeukaryotes were operationally defined by the peak channel of FSC for $3.0 \mu \mathrm{m}$ polystyrene calibration beads (Spherotech; determined at least once daily). A $70 \mu \mathrm{m}$ nozzle tip was used with a sample pressure of 28.5 PSI (+1.0 PSI over sheath) to optimize speed while maintaining high fluorescent signal resolution. Sheath fluid was made fresh daily from deionized water (Milli-Q, Millipore) and molecular grade $\mathrm{NaCl}$ (Mallinckrodt Baker) and was filtered through a $0.2 \mu \mathrm{m}$ capsule filter (Pall Life Sciences). A $100 \mathrm{~mW}$ blue $(488 \mathrm{~nm})$ excitation laser, run at full power, was used in conjunction with 3 color and 2 scatter detectors. Analog signals from red longpass (>650 nm), orange $(585 / 30 \mathrm{~nm})$ and green $(530 / 20 \mathrm{~nm})$ bandpass filters, as well as direct laser light from forward and side scatter (FSC, SSC) detectors (Hamamatsu C6270 photomultiplier tubes), were log amplified and digitally converted at 16 bits. Mean coincident abort rates were $<1 \%$, and mean recovery from secondary sorts $(\mathrm{n}=25)$ was $97.5 \pm 1.1 \%$ (data not shown). Spigot $^{\mathrm{TM}}$ (Becton Dickinson) was used for data acquisition, and FCS Express V3 ${ }^{\mathrm{TM}}$ (DeNovo Software) was used for post-acquisition analysis.

P utilization rates. Sorted cells from each sample were filtered onto $0.2 \mu \mathrm{m}$ Nucleopore polycarbonate filters under low vacuum $(<50 \mathrm{~mm} \mathrm{Hg})$ and rinsed with copious amounts of $0.2 \mu \mathrm{m}$ filtered seawater; scintillation cocktail (AquaSol or Ultima Gold, Perkin Elmer Life and Analytical Sciences) was added, and the solution was shaken and counted on a Hewlett Packard TriCarb 2900 liquid scintillation counter. Cell-specific utilization rates were calculated as:

$$
\rho_{\mathrm{P} i}=\left(\frac{\beta_{\text {sort }}}{n}\right)^{\left(\frac{\ln 2 \times \Delta T}{\lambda}\right)} \cdot\left(\frac{P}{\beta_{\mathrm{TA}} \times T_{\mathrm{inc}}}\right)
$$

where $\rho_{\mathrm{P} i}$ is the cell-specific utilization rate $\left(\mathrm{amol}^{33} \mathrm{P} i\right.$ or $\mathrm{AT}^{33} \mathrm{P}$ cell $\left.^{-1} \mathrm{~h}^{-1}\right), \beta_{\text {sort }}$ and $\beta_{\mathrm{TA}}$ are the $\beta$-emission activities (counts $\mathrm{min}^{-1}$ ) for the sorted sample and the total activity added, respectively, $n$ is the number of cells sorted, $\Delta T$ is the elapsed time from ${ }^{33} \mathrm{P}$ isotopic tracer addition to counting, $T_{\text {inc }}$ is the incubation duration, $\lambda$ is the decay constant of ${ }^{33} \mathrm{P}$ (half life $=25.4 \mathrm{~d}$ ), and $P$ is the ambient concentration of the $\mathrm{P}$ source $\left(\mathrm{nmol} \mathrm{l}^{-1}\right)$. SRP concentrations were measured directly for all samples. An ATP concentration of $1 \mathrm{nmol} \mathrm{l}^{-1}$ was assumed based upon chemical data collected in the North Pacific (Karl \& Bossard 1985) and bioassay measurable ATP in the North Atlantic (Zubkov et al. 2007). ATP concentrations likely vary within the study area; hence, we refer to ATP uptake rates using a constant ATP concentration as $\rho^{*}$ ATP. The implications of using a constant ATP concentration are discussed below. We routinely sorted varying numbers of cells from the same incubation sample and plotted counts per minute (CPM) against the number of cells sorted, but this was not done for every sample (Fig. 2). Utilization rates based upon a single sorted sample were not significantly different from utilization rates using the slope of CPM versus cell number on the same sample (data not shown). The $y$-intercept of this type of calibration curve represents one way to estimate the sort contamination by non-target cells. That is to say, if heterotrophic bacteria, for example, were coincidently sorted with Prochlorococcus, their contribution to CPM would scale with target cell number effectively creating an offset and a $y$-intercept $>0$. In all cases, the $y$-intercepts estimated from the linear regressions were not significantly different from the blanks (clean scintillation vial, filter and cocktail, no target cells). Therefore,

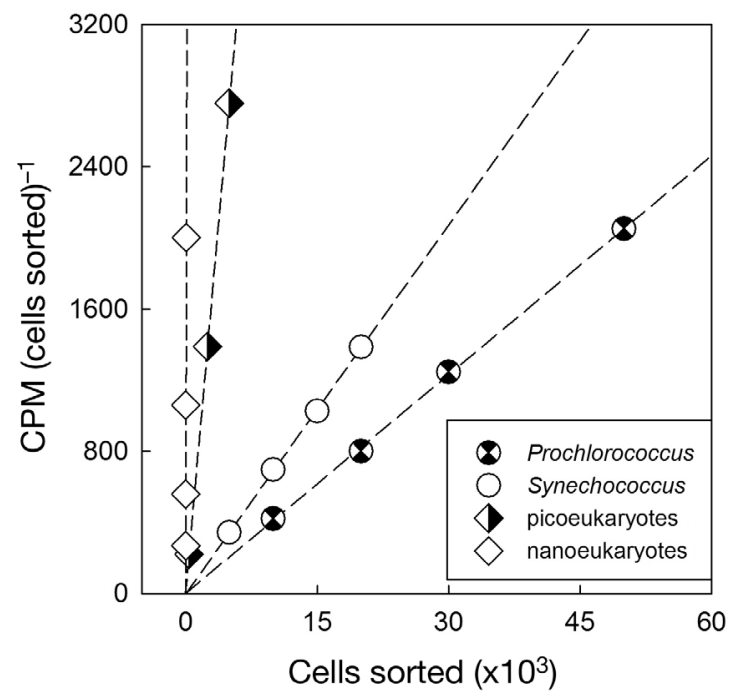

Fig. 2. Examples of ${ }^{33} \mathrm{Pi}$ (orthophosphate) utilization (presented as counts per minute, CPM) as a function of the number of cells sorted for each of the taxonomic groups discussed in this manuscript (see key). Dashed lines are least-squares linear regressions, CPM intercepts of all regressions are not significantly different from zero $(p>0.1)$ 
the use of a single sorted sub-sample is appropriate for estimating utilization rates. Cell surface adsorption of the radioisotope tracer was taken into account by subtracting the rate calculated for the killed controls from the corresponding live utilization rate. Although these were small portions of the total substrate utilization (usually $<10 \%$ ), this term probably is an overestimate of adsorption as fixation by paraformaldehyde is known to permeabilize cell membranes and provides a larger substrate-binding surface area than live cells. Calculation of population-specific $\mathrm{P}$ uptake was derived by multiplying cell-specific uptake rates and cell abundances.

Flow cytometry-derived chlorophyll and autotrophic biovolume estimates. Relative contributions to total flow cytometer-based chlorophyll ( $\mathrm{chl}_{\mathrm{FCM}}$ ) and autotrophic biovolume (ABV) were calculated using red fluorescence and FSC (relative units), respectively. For $\mathrm{chl}_{\mathrm{FCM}}$ the red fluorescence geometric mean area for a specific target cell gate $\left(\mu_{\text {gate }}\right)$ was compared to the red fluorescence geometric mean area of all autotrophic cells $\left(\mathrm{RFL}_{\mathrm{FSC}+}\right)$. For ABV, the FSC geometric mean area for a specific target cell gate was compared to the total FSC area of all autotrophic cells $\left(\mathrm{FSC}_{\mathrm{RFL}+}\right)$, such that:

$$
\begin{gathered}
\operatorname{chl}_{\mathrm{FCM}}=\frac{\mu_{\text {gate }}}{\sum \mathrm{RFL}_{\mathrm{FSC}+}} \\
\mathrm{ABV}=\frac{\mu_{\text {gate }}}{\sum \mathrm{FSC}_{\mathrm{RFL}+}}
\end{gathered}
$$

The red fluorescence (692/40 nm) detection includes all derivatives of chlorophyll, so no comparison was made to chl a extracted from whole seawater. In addition, it should be noted that ABV is not always proportional to biomass, because the conversion from FSC to carbon per cell volume is not necessarily linear and scatter signals differ due to the various optical bench designs that measure Mie-type scattering (DuRand et al. 2001). Therefore, relationships between light scatter and particle diameter were determined daily and on the same cytometer used for analysis. Particle diameter and FSC were always found to follow a positive linear relation $\left(\mathrm{r}^{2}>0.95\right.$, Model I linear regression) on a log-log scale as determined by using $0.53,3.0$, and $6.0 \mu \mathrm{m}$ polystyrene calibration beads (Spherotech). Cell volume was calculated assuming all particles were spheres, such that:

$$
V=\frac{4}{3} \times \pi\left(\frac{\alpha}{2} \times m+b\right)^{3}
$$

where $V$ is the mean cell volume $\left(\mu \mathrm{m}^{3}\right), \alpha$ is the logtransformed geometric mean FSC of the target gate, $m$ and $b$ are the slope and intercept of the Model I linear regression of FSC and the calibration bead diameter.
Bulk APA. For APA samples, $300 \mathrm{ml}$ of seawater was collected on a $0.2 \mu \mathrm{m}$ filter and the filters were stored frozen at $-20^{\circ} \mathrm{C}$. Samples were processed as described elsewhere (Dyhrman \& Ruttenberg 2006). Briefly, $10 \mu \mathrm{mol} \mathrm{l^{-1 }}$ 6,8-difluoro-4-methylumbelliferyl phosphate (di-MUF-P) (Invitrogen) was added to each sample in a Petri dish with artificial seawater containing no added $\mathrm{P}$, and fluorescence was measured on a Fluostar Optima plate reader (BMG Labtech) every 5 to $20 \mathrm{~min}$ at 5 time points, within the linear range of the assay. Previous kinetics experiments found the $10 \mu \mathrm{mol} \mathrm{l}^{-1}$ substrate concentration to be saturating (data not shown). Standard curves were generated for each assay using 6,8-difluoro-7-hydroxy-4-methylcoumarin (di-MUF) as a standard.

Statistical methods. Unless otherwise noted, a general linear model analysis of variance (ANOVA) was used to compare trends in treatments of normally distributed data using the statistics package Minitab (Minitab) or SigmaStat (Systat Software). Where data distributions failed normality tests, an appropriate transform was chosen according to Quinn \& Keough (2002). When $>2$ treatments were analyzed simultaneously, a fully nested ANOVA was used. All statistical tests were tested for significance at the $\mathrm{p}<0.05$ level.

\section{RESULTS}

\section{$P$ concentrations}

SRP concentrations were almost always $<5 \mathrm{nmol}^{-1}$ in the upper $50 \mathrm{~m}$ during both cruises, with generally higher concentrations found at the DCM (Table 1) Averaged across all depths and stations, SRP comprised $16 \pm 29 \%$ (mean \pm SD) of the TDP pool during X0705 and $8 \pm 10 \%$ during BVal39. DOP ([TDP] [SRP]) concentrations were $57.3 \pm 29.1 \mathrm{nmol} \mathrm{l}^{-1}$ for X0705 and $84.8 \pm 30.7 \mathrm{nmol}^{-1}$ for BVal39, and were statistically uniform with depth for both cruises $(\mathrm{p}<$ 0.05). DOP was the major component of TDP, averaging $84 \pm 29 \%$ for X0705 and $92 \pm 10 \%$ for BVal39. PP concentrations averaged over the upper $120 \mathrm{~m}$ were $12.3 \pm 5.8 \mathrm{nmol} \mathrm{l}^{-1}$ for X0705 and $3.3 \pm 0.9 \mathrm{nmol} \mathrm{l}^{-1}$ for BVal39. PP accounted for $17.2 \pm 11.3$ and $4.3 \pm 3.8 \%$ (BVal39) of the combined dissolved and particulate $\mathrm{P}$ pool.

\section{Phytoplankton community composition}

The DCM varied in depth and concentration depending on latitude and season. The DCM depth was closely associated with the $\rho_{1}=26.0 \mathrm{~kg} \mathrm{~m}^{-3}$ isobar and $1 \%$ isolume for both cruises. The DCM during 
X0705 shoaled and increased in magnitude from south

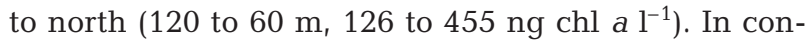
trast, the BVal39 DCM was relatively stable at $\sim 100 \mathrm{~m}$, except for the southernmost station, where it shoaled to $80 \mathrm{~m}$, with chl a concentrations highest (365 ng chl a $\mathrm{l}^{-1}$ ) near Bermuda (Table 1).

The major autotrophic constituents distributed within the euphotic zone as determined by flow cytometry were, in order of numerical dominance: Prochlorococcus, Synechococcus, pico- $(<3 \mu \mathrm{m})$, and nanoeukaryotes (3 to $10 \mu \mathrm{m})$. Prochlorococcus and picoeukaryote cell abundance maxima coincided with the DCM (Fig. 3). Prochlorococcus cell abundances at the DCM were $5 \times 10^{4}$ to $2 \times 10^{5} \mathrm{ml}^{-1}$, with lower abundances (ca. $1 \times 10^{4} \mathrm{ml}^{-1}$ ) near the surface. Despite similar cell abundances, Prochlorococcus cells throughout the entire euphotic zone were larger and brighter in red fluorescence (i.e. chlorophyll) during BVal39 than during X0705. In contrast, Synechococcus cells were brighter, larger, and more abundant for X0705 samples than for BVal39 samples. Surface Synechococcus populations were generally 30 to $60 \%$ of $\mathrm{chl}_{\mathrm{FCM}}$ and 30 to $40 \%$ of ABV during both cruises. Picoeukaryotes were the largest component (ca. 50\%) of phytoplankton $\mathrm{Chl}_{\mathrm{FCM}}$ and $\mathrm{ABV}$ averaged over the upper $250 \mathrm{~m}$ during X0705, whereas during BVal39 they were supplanted by Prochlorococcus and only contributed ca. $25 \%$. Nanoeukaryotes showed no consistent spatial pattern and were ubiquitous in low abundance for X0705 (48 \pm 43 cells ml $\left.\mathrm{m}^{-1}\right)$ and for BVal39 $\left(33 \pm 47\right.$ cells $\left.\mathrm{ml}^{-1}\right)$ and were a minor contributor to $\mathrm{chl}_{\mathrm{FCM}}$ and $\mathrm{ABV}$ (Fig. 3).

\section{Pi and ATP utilization}

Whole seawater utilization of Pi $\left(\rho_{\mathrm{Pi}}\right)$ and ATP $\left(\rho^{*}{ }_{\text {ATP }}\right)$ varied with depth and season (Fig. 4). Whole-seawater $\rho^{*}$ ATP was 2- to 4 -fold higher during BVal39 than during X0705 throughout the sampling region at all depths $(p<0.05)$, while $\rho_{P i}$ remained similar between cruises $(p=0.81)$. X0705 $\rho_{\mathrm{P} i}$ and $\rho^{*}{ }_{\text {ATP }}$ maxima occurred from 20 to $40 \mathrm{~m}$ at all stations, whereas during BVal39 $\rho_{\text {Pi }}$ and $\rho^{*}{ }_{\text {ATP }}$ were much more variable and as a result statistically uniform with depth $(p<0.05)$. Mean whole-seawater $\rho^{*}$ ATP as a percentage of $\rho_{\mathrm{P} i}$ was significantly lower for X0705 (0.8 $\pm 0.4 \%$; p < 0.05) than for BVal39 $(13.9 \pm 23.4 \%)$.

Contributions of various microbial groups to total uptake were different compared with the eastern subtropical North Atlantic (Zubkov et al. 2007). Heterotrophic bacteria dominated Pi and ATP uptake on both cruises; those results will be presented elsewhere (V. K. Michelou, M. W. Lomas, D. L. Kirchman unpubl. data). Amongst the autotrophic groups in the western North Atlantic, cyanobacterial uptake of $\mathrm{P}$ was always greater than uptake by eukaryotes, but no clear distinction between the cyanobacterial groups Prochlorococcus and Synechococcus occurred, in contrast to the situation in the eastern North Atlantic. At the population level, Prochlorococcus and Synechococcus accounted for similar contributions to total Pi uptake, 2 to $8 \%$ depending upon the cruise, while their contributions to ATP uptake ranged from 3 to $20 \%$. Eukaryotic uptake of Pi and ATP was always
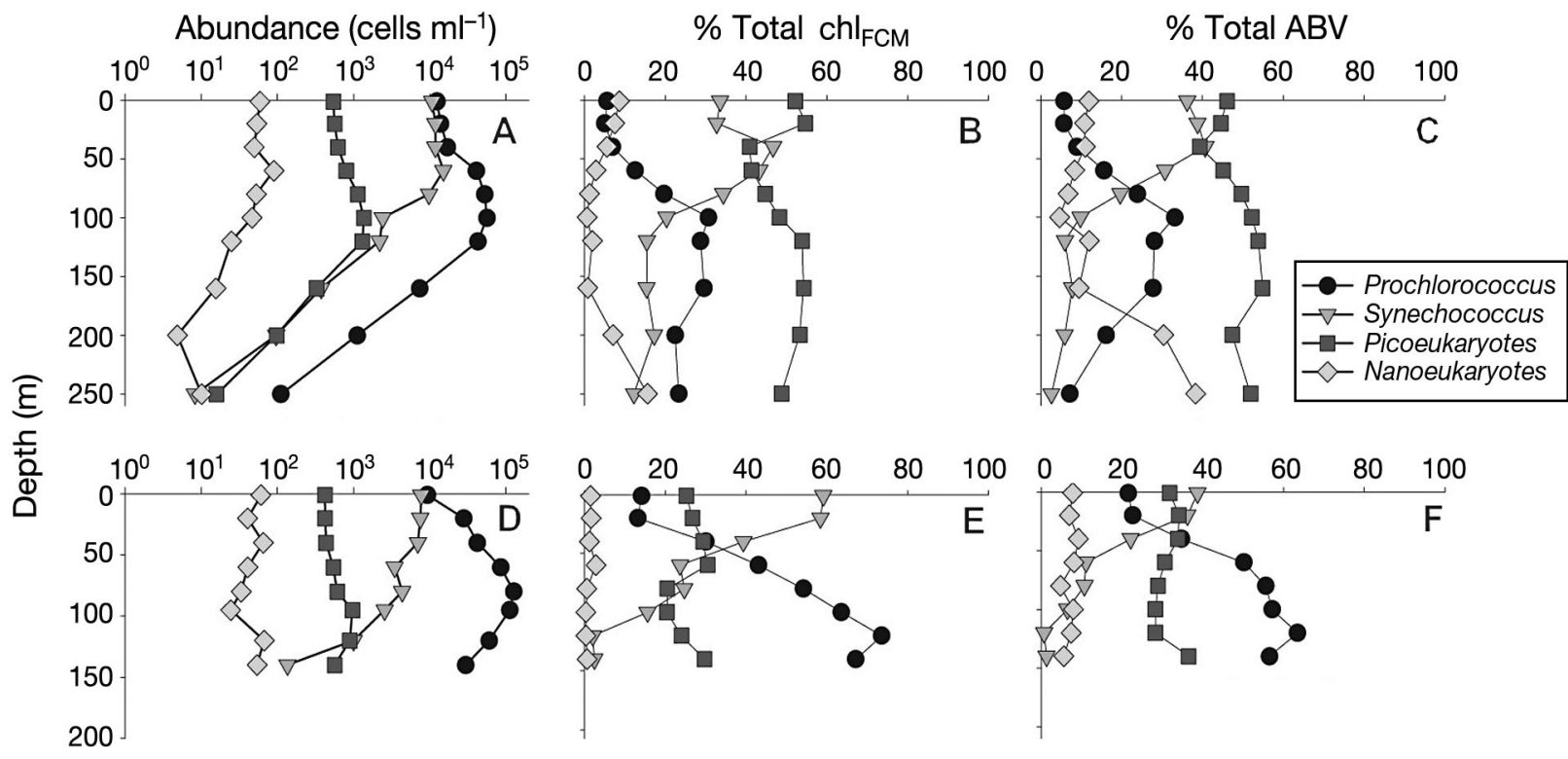

Fig. 3. (A,D) Depth profiles of mean cell abundance $\left(\right.$ cells $\left.\mathrm{ml}^{-1}\right)$; and $(\mathrm{B}, \mathrm{E})$ percent contributions to flow cytometrically derived red fluorescence $\left(\mathrm{chl}_{\mathrm{FCM}}\right)$ and $(\mathrm{C}, \mathrm{F})$ autotrophic biovolume $(\mathrm{ABV})$ for populations of 4 taxonomic groups (see key) during Cruise X0705 (A to C) and Cruise BVal39 (D to F). See 'Materials and methods' for details of calculations 
$<3 \%$, with the exception of ATP uptake during BVal39, where eukaryotes represented $12 \%$ of total ATP uptake.

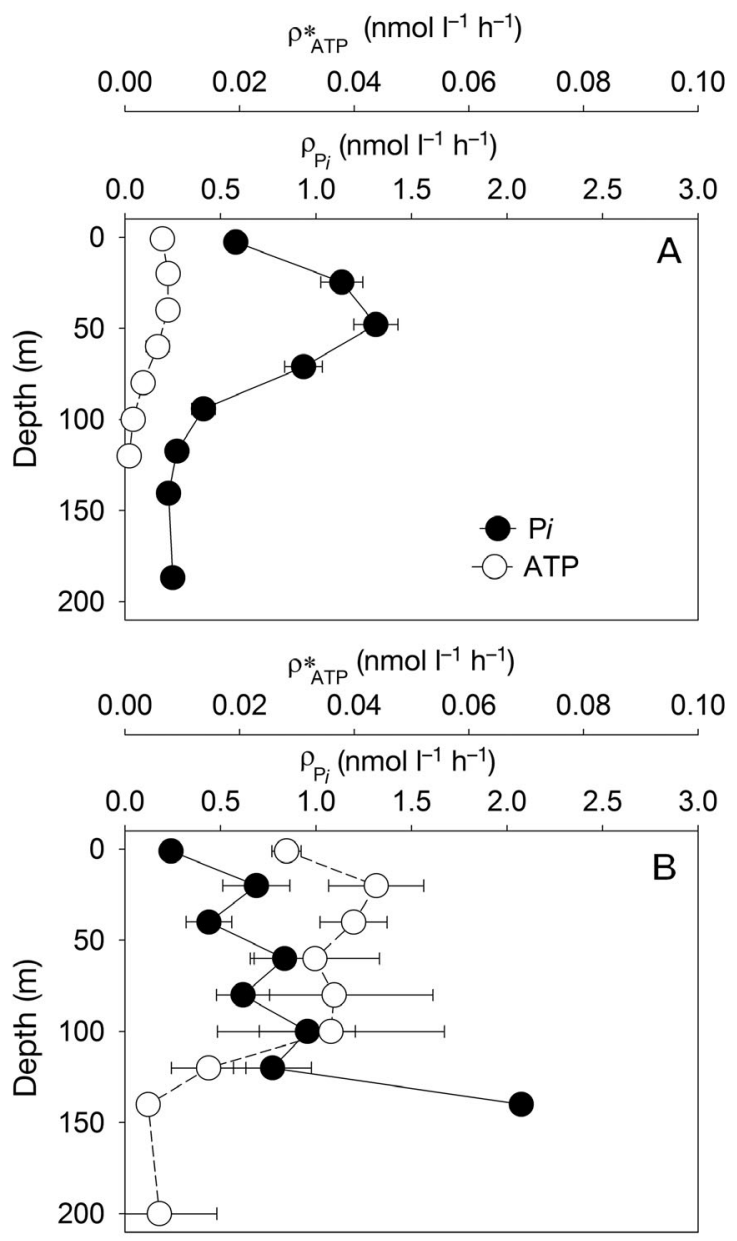

Fig. 4. Depth profiles of whole community ${ }^{33} \mathrm{Pi}$ (orthophosphate; filled circles) and $\mathrm{dAT}^{33} \mathrm{P}$ (adenosine 5 'triphosphate; open circles) utilization rates $\left(\mathrm{nmol} \mathrm{l}^{-1} \mathrm{~h}^{-1}\right)$, averaged for all stations during (A) Cruise X0705 and (B) Cruise BVal39. Error bars are $\pm 1 \mathrm{SD}$
All sorted phytoplankton groups were clearly capable of both Pi and ATP utilization (Table 2). Taxon-specific utilization rates (amol cell ${ }^{-1} \mathrm{~h}^{-1}$ ) for both substrates increased with cell type in the order Prochlorococcus, Synechococcus $s_{\perp}$ pico-, and nanoeukaryotes, and with depth within each cell type. This was primarily the result of an increase in mean cell size both between groups and within each group as a function of depth; normalized data on cell biovolume reflect physiological differences in response to the ambient nutrient environment (Table 3). It is worth noting that utilization was not completely compensated for by changes in cell biovolume, as average rates often increased from 2- to 3-fold in the DCM, but were highly variable. Synechococcus biovolume normalized $\rho_{\mathrm{P} i}$ and $\rho^{*}{ }_{\text {ATP }}$ were significantly $(\mathrm{p}<0.001)$ greater than all other groups in most instances, followed by Prochlorococcus, which was significantly greater than picoeukaryotes and nanoeukaryotes (Table 3). Seasonally, log-normalized taxon-specific $\rho_{\mathrm{P} i}$ were significantly lower for X0705 than for BVal39 ( $\mathrm{p}<0.001)$, with the exception of Prochlorococcus $\rho_{\mathrm{P} i}(t=0.737, \mathrm{df}=33$, $\mathrm{p}=0.466)$, which were similar between cruises. A similar observation was apparent for $\rho^{*}$ ATP, except only Synechococcus and picoeukaryotes showed a significant seasonal increase (Table 3).

\section{DISCUSSION}

We modified a method combining flow cytometric sorting and stable isotope tracer protocols (FLOW-SIP) for environmental samples collected in the Sargasso Sea; this method was previously developed by our laboratory (Casey et al. 2007) to accommodate radioisotope tracers and was similar to the methods of Zubkov et al. (2007) and Larsen et al. (2008). With our method, environmental samples can be incubated with a minimum of manipulations in whole seawater while emu-

Table 2. Average counts per minute $(\mathrm{CPM})$ per cell $( \pm 1 \mathrm{SD})$ for each cruise. Averages are for all stations and depths during each cruise. All values were normalized with a $10^{6} \mathrm{CPM}$. Adenosine 5 'triphosphate to orthophosphate (ATP:Pi) is the ratio of CPM per cell expressed as a percent for all phytoplankton groups and for whole seawater (which would include bacterial contributions to $\mathrm{P}$ utilization)

\begin{tabular}{|c|c|c|c|c|c|c|c|}
\hline \multirow[t]{2}{*}{ Cruise } & \multirow[t]{2}{*}{ Cell type } & \multicolumn{2}{|l|}{$\mathrm{Pi}_{-}$} & \multicolumn{2}{|c|}{ ATP } & \multicolumn{2}{|c|}{ ATP:Pi $(\%)$} \\
\hline & & $\mathrm{CPM}_{\mathrm{cell}}{ }^{-1}$ & $\mathrm{SD}$ & CPM cell ${ }^{-1}$ & $\mathrm{SD}$ & Phytoplankton & Whole seawater \\
\hline \multirow[t]{4}{*}{ X0705 } & Prochlorococcus & 0.0063 & 0.0015 & 0.0019 & 0.0008 & \multirow[t]{4}{*}{$58 \pm 20 \%$} & \multirow[t]{4}{*}{$28 \pm 28 \%$} \\
\hline & Synechococcus & 0.0180 & 0.0034 & 0.0104 & 0.0028 & & \\
\hline & Picoeukaryotes & 0.0864 & 0.0179 & 0.0596 & 0.0199 & & \\
\hline & Nanoeukaryotes & 0.7249 & 0.0710 & 0.5540 & 0.1953 & & \\
\hline \multirow[t]{4}{*}{ BVal39 } & Prochlorococcus & 0.0035 & 0.0020 & 0.0011 & 0.0005 & \multirow[t]{4}{*}{$67 \pm 41 \%$} & \multirow[t]{4}{*}{$25 \pm 50 \%$} \\
\hline & Synechococcus & 0.0315 & 0.0206 & 0.0397 & 0.0320 & & \\
\hline & Picoeukaryotes & 0.1558 & 0.0387 & 0.0939 & 0.0367 & & \\
\hline & Nanoeukaryotes & 0.7055 & 0.2571 & 0.3399 & 0.1025 & & \\
\hline
\end{tabular}


Table 3. Biovolume-normalized assimilated orthophosphate $\left(\rho_{\mathrm{P} i}\right)$ and assimilated adenosine $5^{\prime}$ triphosphate $\left(\rho^{*}\right.$ ATP). MannWhitney rank sum tests were carried out for significant differences between taxonomic groups, given in the order $a>b>c>d$, and between depths, given in the order $1<2<3$. Bold numbers indicate a significant increase within a group between the 2 cruises. DCM: depth of the deep chlorophyll maximum

\begin{tabular}{|c|c|c|c|c|c|c|c|c|c|}
\hline & & \multicolumn{8}{|c|}{ Biovolume-normalized utilization rates (amol $\mu \mathrm{m}^{-3} \mathrm{~h}^{-1}$ ) } \\
\hline & & $\rho_{\mathrm{p} i}$ & $\begin{array}{l}\text { - Crui } \\
\text { SD }\end{array}$ & $\begin{array}{l}\mathbf{X} 0705 \\
\rho_{\text {АTP }}^{*}\end{array}$ & $\overline{\mathrm{SD}}$ & & $\begin{array}{l}\text { Cruis } \\
\text { SD }\end{array}$ & $\begin{array}{c}\text { Val39 } \\
\rho^{*} \text { АТР }\end{array}$ & SD \\
\hline Prochlorococcus & $\begin{array}{l}\text { Surface } \\
40 \mathrm{~m} \\
\text { DCM } \\
\text { Mean }\end{array}$ & $\begin{array}{l}4.74^{1} \\
3.66^{1} \\
3.99^{1} \\
4.12^{\mathrm{a}}\end{array}$ & $\begin{array}{l}6.10 \\
3.07 \\
4.28 \\
0.24\end{array}$ & $\begin{array}{l}0.49^{1} \\
0.70^{1} \\
0.82^{1} \\
0.67^{b}\end{array}$ & $\begin{array}{l}0.16 \\
0.49 \\
0.39 \\
0.38\end{array}$ & $\begin{array}{l}1.71^{1} \\
4.25^{2} \\
9.56^{3} \\
6.28^{\mathrm{b}}\end{array}$ & $\begin{array}{l}0.66 \\
4.32 \\
7.70 \\
0.35\end{array}$ & $\begin{array}{l}0.86^{1} \\
0.71^{1} \\
0.51^{1} \\
0.69^{b}\end{array}$ & $\begin{array}{l}0.40 \\
0.49 \\
0.20 \\
0.39\end{array}$ \\
\hline Synechococcus & $\begin{array}{l}\text { Surface } \\
40 \mathrm{~m} \\
\text { DCM } \\
\text { Mean }\end{array}$ & $\begin{array}{l}5.86^{1} \\
8.36^{1} \\
7.70^{1} \\
7.54^{\mathrm{a}}\end{array}$ & $\begin{array}{c}5.33 \\
10.89 \\
7.53 \\
0.47\end{array}$ & $\begin{array}{l}2.16^{1} \\
1.49^{1} \\
2.67^{1} \\
2.11^{\mathrm{a}}\end{array}$ & $\begin{array}{l}1.03 \\
0.87 \\
1.23 \\
1.11\end{array}$ & $\begin{array}{l}14.33^{1} \\
22.29^{1} \\
42.01^{2} \\
\mathbf{1 6 . 6 5}^{\mathbf{a}}\end{array}$ & $\begin{array}{c}12.58 \\
22.70 \\
28.80 \\
1.11\end{array}$ & $\begin{array}{l}5.81^{1} \\
8.94^{1} \\
5.68^{1} \\
\mathbf{7 . 2 4}\end{array}$ & $\begin{array}{l}4.71 \\
6.71 \\
9.05 \\
5.54\end{array}$ \\
\hline Picoeukaryotes & $\begin{array}{l}\text { Surface } \\
40 \mathrm{~m} \\
\text { DCM } \\
\text { Mean }\end{array}$ & $\begin{array}{l}0.19^{1} \\
0.39^{1} \\
1.35^{2} \\
0.64^{\mathrm{b}}\end{array}$ & $\begin{array}{l}0.13 \\
0.40 \\
2.60 \\
0.08\end{array}$ & $\begin{array}{l}0.09^{1} \\
0.10^{1} \\
0.28^{1} \\
0.15^{\mathrm{c}}\end{array}$ & $\begin{array}{l}0.04 \\
0.10 \\
0.16 \\
0.14\end{array}$ & $\begin{array}{l}1.06^{1} \\
1.24^{1} \\
2.31^{1} \\
\mathbf{1 . 6 5}^{\mathbf{c}}\end{array}$ & $\begin{array}{l}0.82 \\
1.10 \\
2.58 \\
0.10\end{array}$ & $\begin{array}{l}0.24^{1} \\
0.32^{1} \\
0.44^{2} \\
\mathbf{0 . 3 2}^{\mathbf{c}}\end{array}$ & $\begin{array}{l}0.08 \\
0.17 \\
0.11 \\
0.15\end{array}$ \\
\hline Nanoeukaryotes & $\begin{array}{l}\text { Surface } \\
40 \mathrm{~m} \\
\text { DCM } \\
\text { Mean }\end{array}$ & $\begin{array}{l}0.03^{1} \\
0.05^{1} \\
0.09^{1} \\
0.06^{\mathrm{c}}\end{array}$ & $\begin{array}{l}0.03 \\
0.06 \\
0.14 \\
0.00\end{array}$ & $\begin{array}{l}0.02^{1} \\
0.01^{1} \\
0.03^{1} \\
0.02^{\text {d }}\end{array}$ & $\begin{array}{l}0.01 \\
0.01 \\
0.01 \\
0.01\end{array}$ & $\begin{array}{l}0.05^{1} \\
0.08^{1} \\
0.15^{2} \\
\mathbf{0 . 1 1}^{\mathbf{d}}\end{array}$ & $\begin{array}{l}0.02 \\
0.09 \\
0.11 \\
0.01\end{array}$ & $\begin{array}{l}0.02^{1} \\
0.02^{1} \\
0.02^{1} \\
0.02^{\mathrm{d}}\end{array}$ & $\begin{array}{l}0.01 \\
0.00 \\
0.01 \\
0.01\end{array}$ \\
\hline
\end{tabular}

lating natural conditions and eliminating many biases inherent in laboratory-based determinations of taxonspecific nutrient utilization rates.

There are 2 caveats to the data presented here that could potentially impact the presentation and interpretation of these data: differential leakage of $\mathrm{P}$ from sorted autotrophic groups and an assumed ATP concentration. Tests of isotope leakage from cells upon fixation are similar to those previously observed under similar conditions (Larsen et al. 2008). In addition, no statistically significant differences were found in the percent of isotope released between the various flowsorted autotrophic groups (data not shown). These observations, in conjunction with the results from separate killed controls (which accounts for cell surface binding), suggest that the mechanism by which this leakage occurs is related to the disruption of the cell membrane upon fixation and the leakage of internal $\mathrm{P}$ pools - something that happens to all cells upon fixation. Moreover, because there were no discernable differences in leakage between flow-sorted cell populations, conclusions drawn in the present study comparing different groups are not impacted, although the absolute rates would be reduced in comparison to studies that did not use fixatives. Rates of ATP uptake in the present study were calculated using an ATP concentration of $1 \mathrm{nmol} \mathrm{l}^{-1}$, an upper value seen in the eastern North Atlantic (Zubkov et al. 2007), although the lower limit of observed concentrations was $\sim 0.5 \mathrm{nmol} \mathrm{l}^{-1}$. Uptake rates are proportional to substrate concentration so a 2 -fold range in concentrations would yield a 2-fold range in uptake rates. Using an assumed ATP concentration may increase variability when comparing a single group across many stations (e.g. Fig. 5). In addition, using an assumed ATP concentration will impact comparisons between $\mathrm{P} i$ and ATP uptake within a group. Data on the ratio of ATP:P $i$ radioactivity per cell, a value not effected by uncertainties in either concentration estimate, suggests that ATP uptake is $>30 \%$ of Pi uptake (Table 2). Data on the ratio of ATP:Pi uptake rate per cell are very similar, ranging from 0.1 to 1 (Fig. 6) and suggesting that the use of an assumed concentration has not compromised the interpretation of relative $\mathrm{P}$ uptake within a specific autotrophic group. Lastly, given that all autotrophic groups at the same station/depth would be exposed to the same ambient nutrient concentrations, an assumed ATP concentration does not impact conclusions comparing different autotrophic groups: although perhaps off in magnitude due to an assumed ATP concentration, rates will be internally consistent and comparisons valid.

\section{Taxon-specific utilization of $P$ in the western sub- tropical North Atlantic}

In the western subtropical North Atlantic, all sorted groups of picophytoplankton (Prochlorococccus, Synechococcus, picoeukaryotes, and nanoeukaryotes) were capable of assimilating $\mathrm{P} i$ and ATP. However, there were clearly physiological differences between pico- 

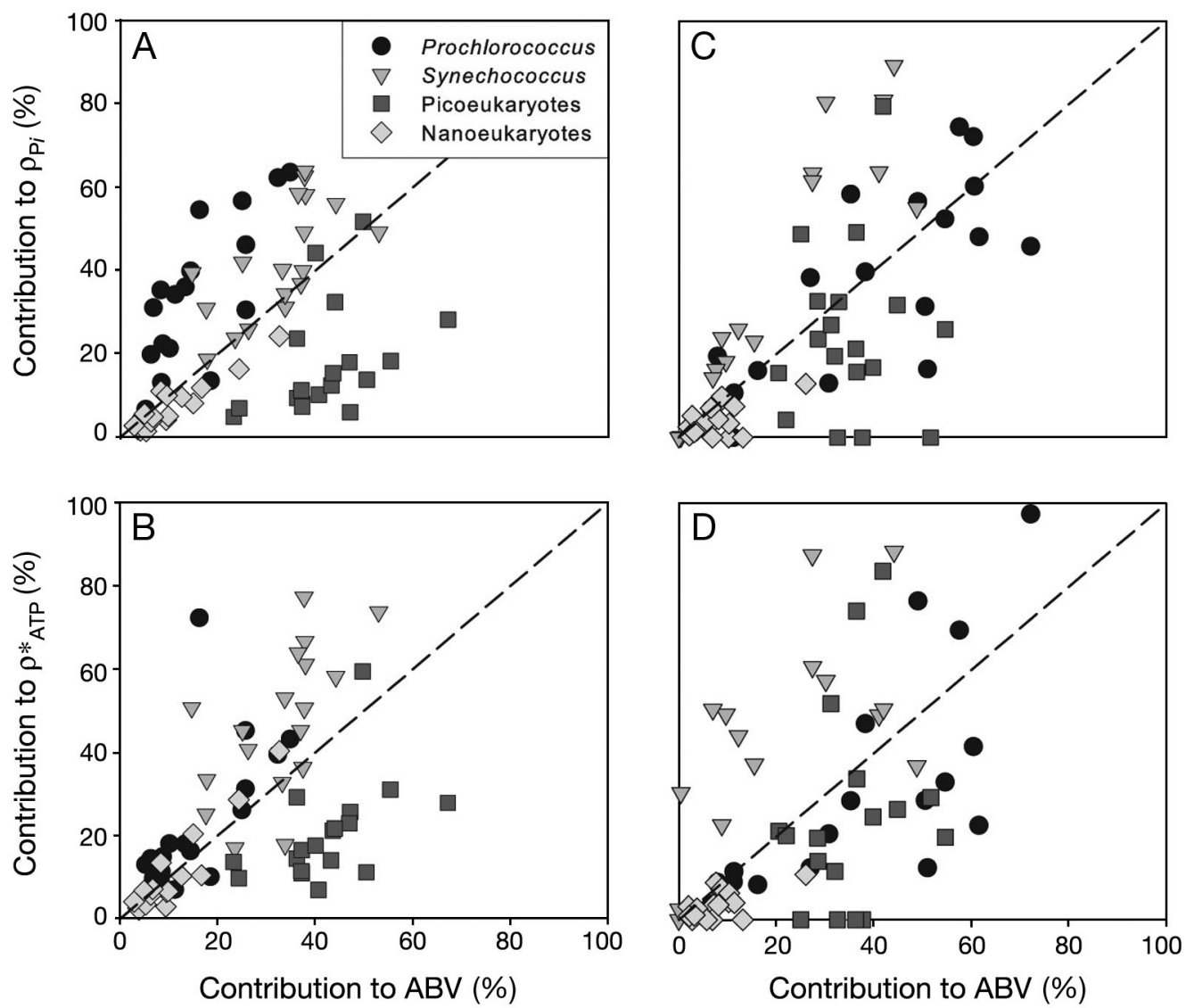

Fig. 5. Percent contribution of each taxonomic group to total phytoplankton $(A, C)$ assimilated orthophosphate $\left(\rho_{P_{i}}\right)$ and $(B, D)$ assimilated adenosine $5^{\prime}$ triphosphate $\left(\rho^{*}{ }_{\text {ATP}}\right)$ as a function of percent contribution to autotrophic biovolume (ABV) during Cruise $\mathrm{X} 0705(\mathrm{~A}, \mathrm{~B})$ and Cruise BVal39 (C,D). Symbols are as in Fig. 3; a 1:1 reference line (dashed line) is given

planktonic groups. Synechococcus biovolume-normalized utilization rates for both Pi and ATP were highest among the groups investigated, followed by Prochlorococcus, picoeukaryotes, and nanoeukaryotes; nearly all comparisons were significant (Table 3). A likely explanation for these differences in physiological capacity is that the cyanobacteria have evolved more efficient systems for nutrient acquisition in oligotrophic systems. Martiny et al. $(2006,2009)$ have hypothesized that, for Prochlorococcus, there is an inverse relationship between P-related gene compliment and ambient SRP concentrations; above $\sim 100 \mathrm{nmol} \mathrm{l}^{-1}$, natural Prochlorococcus populations lack many of the genes for efficient $\mathrm{P}$ scavenging. It remains to be seen whether the diverse picoeukaryote populations in the Sargasso Sea display similar patterns (e.g. Not et al. 2007).

These physiological differences also appear to have an effect at the population level. Synechococcus $\rho_{\mathrm{P} i}$ and $\rho^{*}{ }_{\text {ATP }}$ utilization rates are sufficiently high to outweigh lower cell abundances, such that Synechococcus frequently $(\sim 80 \%$ of observations) contributed more to measured $\mathrm{P}$ utilization than to $\mathrm{ABV}$ in a given sample (Fig. 5). Similarly, Prochlorococcus contributed more to $\mathrm{P}$ utilization than $\mathrm{ABV}$, but this was only during X0705; during BVal39, Prochlorococcus contributed equally to $\mathrm{P}$ utilization and ABV. Picoeukaryotes were a significant component of the ABV and $\mathrm{chl}_{\mathrm{FCM}}$ during both cruises, sometimes as high as $54 \%$, but rarely did they contribute that fraction to $\rho_{\mathrm{P} i}$ and $\rho^{*}{ }_{\text {ATP }}$ (contributions to $\rho_{\mathrm{P} i}$ and $\rho^{*}{ }_{\text {ATP }}$ were $19 \pm 14$ and $23 \pm 14 \%$, respectively; Figs. $3 \& 5$ ), and the nanoeukaryotes were generally minor constituents of $\mathrm{ABV}, \mathrm{chl}_{\mathrm{FCM}}, \rho_{\mathrm{P} i}$ and $\rho^{*}{ }_{\mathrm{ATP}}$. We estimated cell volume from FSC, which has been shown to scale with cell carbon (DuRand et al. 2001, Bertilsson et al. 2003). The observation that picoeukaryotes consistently fall below the 1:1 line and that cyanobacteria consistently fall above this line could be explained by (1) all the groups growing at the same rate, but having different cellular C:P ratios or (2) all the groups having similar C:P ratios, but the eukaryotes being more P stressed and, accordingly, growing more slowly.

Using previously published data on taxon-specific 

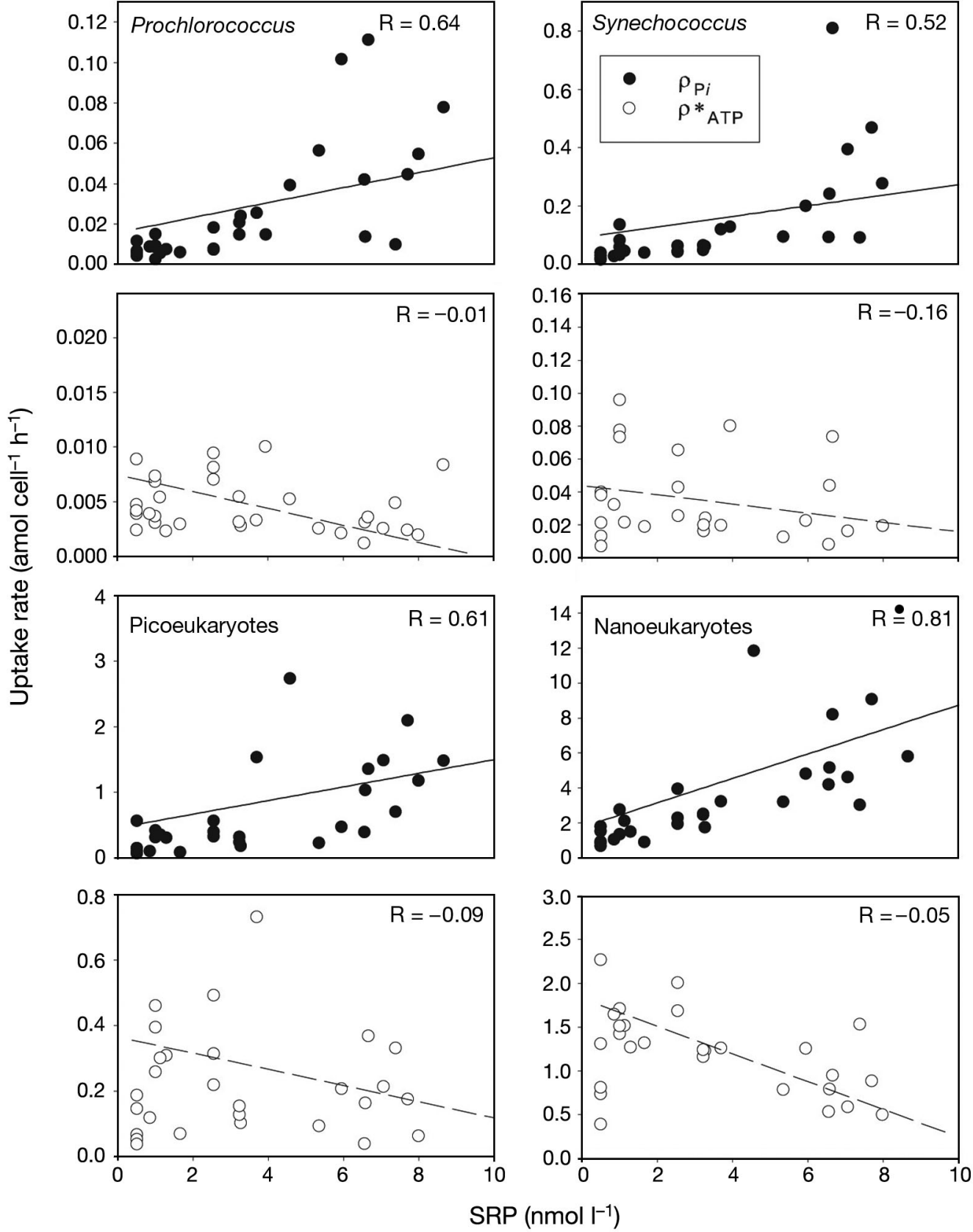

Fig. 6. Cell-specific assimilated orthophosphate $\left(\rho_{\mathrm{P} i}\right.$ amol cell ${ }^{-1} \mathrm{~h}^{-1}$; filled circles) and assimilated adenosine $5^{\prime}$ triphosphate $\left(\rho^{*}{ }_{\text {ATPi }}\right.$ open circles) plotted as a function of ambient soluble reactive phosphorus (SRP) concentration (nmol $\mathrm{l}^{-1}$ ) for each of the phytoplankton taxonmic groups. Data from all depths and cruises are included in each plot. Least-squares correlations are given for Pi (solid line) and ATP (dashed line) in each phytoplankton group. R-values are given in each panel for the respective linear correlations

photosynthetic rates from the North Atlantic (Li 1994) and the data in the present study, we estimated C:P uptake ratios. Calculated C:P utilization ratios for Prochlorococcus range from 45 to 409, and match the range of particulate C:P ratios in cultures remarkably well, i.e. ranging from 121 to 215 in P-replete cultures
(Bertilsson et al. 2003, Heldal et al. 2003) and reaching 464 in P-deplete cultures (Bertilsson et al. 2003). These estimations suggest there may be a range of stress states within natural Prochlorococcus populations. In contrast, calculated C:P ratios for Synechococcus range from 66 to 284, while particulate C:P ratios in P-replete 
cultures range from 113 to 150 (Bertilsson et al. 2003, Heldal et al. 2003) and are 779 in P-deplete cultures (Bertilsson et al. 2003). If the C:P ratio in P-deplete cultures proves to be robust, this would suggest that Synechococcus is less P stressed than Prochlorococcus under the sample conditions; something that has been observed for microhabitats in Trichodesmium colonies (Dyhrman et al. 2002). C:P ratios can only be calculated for the nanoeukaryotes (identified as large eukaryotes in Li 1994), and ratios range from 199 to 267 . These values are at the high end of particulate C:P ratios (42 to 237 ) for a variety of $<10 \mu \mathrm{m}$ eukaryotes (Ho et al. 2003). This suggests that eukaryotes have a higher P demand (relative to $\mathrm{C}$ ) than cyanobacteria, perhaps due to differential abilities to synthesize non-phosphorus lipids (Van Mooy et al. 2009), and also strongly suggests that they are growing more slowly due to greater P stress.

\section{Trans-Atlantic gradients in autotrophic $\mathbf{P}$ utilization}

Zubkov et al. (2007) reported whole seawater SRP utilization rates for eastern North Atlantic surface waters that, on average, were several-fold lower in magnitude $\left(\sim 0.1 \mathrm{nmol} \mathrm{l}^{-1} \mathrm{~h}^{-1}\right.$ in May of 2004 and $\sim 0.15 \mathrm{nmol} \mathrm{l}^{-1} \mathrm{~h}^{-1}$ in October of 2005; data derived from their Fig. 2) than observed in the western North Atlantic ( $\sim .25$ to $0.5 \mathrm{nmol} \mathrm{l}^{-1} \mathrm{~h}^{-1}$; Fig. 4), despite similar SRP concentrations (east, $2.2 \pm 1.2 \mathrm{nmol} \mathrm{l^{-1 }}$; west, $2.5 \pm 2.3 \mathrm{nmol}^{-1}$ ). In addition, results for Pi utilization presented here suggest that Prochlorococcus and Synechococcus contribute statistically similar amounts to autotrophic Pi utilization at the population level. This is different than the conclusion reached by Zubkov et al. (2007), who found that Prochlorococcus contributed $\sim 45 \%$ of measured $\mathrm{P}$ utilization, while Synechococcus contributed only $\sim 7 \%$. One possible explanation for this could be the large gradient in biogeochemical variables (e.g. macronutrient concentrations, rates of export production, and nitrogen fixation) and physical forcing between these regions (i.e. relative contributions of eddy pumping and wintertime convection; Neuer et al. 2002, Cianca et al. 2007) that impacts relative phytoplankton abundances and physiological responses and, perhaps, the difference in total microbial uptake as well. Comparison of cellspecific Pi utilization rates between Prochlorococcus and Synechococcus in the 2 studies (our Fig. 6; Zubkov et al. 2007, their Fig. 5B) show that, while similar, the data of Zubkov et al. (2007) from the eastern North Atlantic show, on average, slightly higher rates than the data from the western North Atlantic. These differences are not sufficient however to explain this discrepancy in population-level P uptake, suggesting the difference at the population level may be due to cell abundance for each population. Indeed, Zubkov et al. (2007) observed Prochlorococcus abundances in excess of $10^{5}$ cells $\mathrm{ml}^{-1}$ in their surface samples, and we

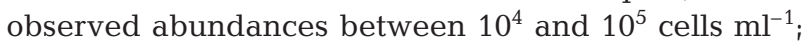
our abundances of Synechococcus tended to be higher than those observed by Zubkov et al. (2007). These differences in the relative abundances of the cyanobacterial groups appear to explain the cross-gyre differences in partitioning of $\mathrm{P}$ uptake by the cyanobacteria.

Zubkov et al. (2007) concluded that nucleotides such as ATP play a secondary role in $\mathrm{P}$ acquisition in the eastern North Atlantic, contributing $\sim 13 \%$, on average. Our data, averaged over the entire dataset suggest that $\rho_{\text {ATP }}^{*}$ is $24 \pm 10 \%$ of $\rho_{\mathrm{Pi}}$ (range: 11 to $44 \%$ ). The different results from these two studies might be explained by differnces in sampling depth. Only surface samples were taken by Zubkov et al. (2007), and we observed substantial differences between surface and DCM utilization rates, so it is possible that extrapolations to a region may underestimate the importance of DOP to support production if not considering the entire euphotic zone. A second explanation could be ecologically important trans-Atlantic gradients in DOP utilization. Mather et al. (2008) calculated saturating rates of DOP hydrolysis by APA in the eastern North Atlantic subtropical gyres to be $0.84 \pm 0.13 \mathrm{nmol} \mathrm{l}^{-1} \mathrm{~h}^{-1}$ ( $\mathrm{n}=5$ ) using surface seawater biomass-specific rates normalized to cell $\mathrm{C}$ by a conversion from chl a to $\mathrm{C}$ (1 g chl a:50 g C). Using this same method and APA rates measured during BVal39 (Table 1), we calculate maximum DOP hydrolysis rates in the western North Atlantic subtropical gyre as $1.53 \pm 0.11 \mathrm{nmol}^{-1} \mathrm{~h}^{-1}(\mathrm{n}=$ 14). While there are caveats with relating APA to ATP uptake (see 'Introduction'), the fact that the majority of the DOP pool is esters (Kolowith et al. 2001) suggests that ATP uptake can be a reasonably good proxy for assessing 'DOP' uptake, and the growing consensus is that 'DOP' plays a critically important role in supporting primary production in the western North Atlantic subtropical gyre.

\section{Interactions between $\mathrm{P} i$ and ATP utilization}

Both $\rho_{\mathrm{P} i}$ and $\rho^{*}$ ATP were plotted as a function of SRP concentration for each of the sorted phytoplankton groups (Fig. 6). In all cases, there was a strong positive linear relationship for $\rho_{\mathrm{P} i}$ over the observed range of SRP concentrations, which would be expected as half-saturation concentrations for Pi utilization by the whole Sargasso Sea community range from 3 to $13 \mathrm{nmol} \mathrm{l}^{-1}$ (Ammerman et al. 2003). Not surprisingly, a weak negative correlation was observed between $\rho^{*}$ ATP and the SRP concentration likely due to upregulation of APA in response to decreases in the ambient 
SRP concentration (e.g. Moore et al. 2005). As a result, the total measured $\mathrm{P}$ utilization within a population was relatively constant over the ambient SRP concentration range. To further illustrate this reciprocity and the potential importance of DOP utilization in SRP-depleted regions, the ratio of $\rho^{*}{ }_{\text {ATP: }} \rho_{\mathrm{P} i}$ as a function of SRP concentration was plotted (Fig. 7). The ratio of $\rho^{*}{ }_{\text {ATP: }} \rho_{\mathrm{P} i}$ increased with decreasing SRP concentration, due to increased $\rho^{*}$ ATP, to the point where $\rho^{*}{ }_{\text {ATP }}$ contributed up to $70 \%$ of total P utilization (i.e. $\rho^{*}{ }_{\text {ATP }}>\rho_{\mathrm{P} i}$ ) when the ambient SRP concentration fell below $3 \mathrm{nmol} \mathrm{l}^{-1}$ (Figs. 6 \& 7). Data points in the range from 3 to $10 \mathrm{nmol} \mathrm{l}^{-1}$ are few, but it appears that there may be some differences between groups when $\rho^{*}$ ATP starts to increase as the SRP concentration decreases. This is likely due to induction of various $\mathrm{P}$-acquisition and P-metabolism pathways, which differ between phytoplankton species, as well as differences in the point where diffusion limitation increases in importance, which is related to cell size (Moutin et al. 2002, Lovdal et al. 2007). These response mechanisms to changing SRP concentrations require that the internal SRP pool is rapidly assimilated into biomass; this characteristic is likely shared by picoplankton in the Sargasso Sea and may explain the higher biovolume-normalized utilization rates in the smaller cells than in the nanoeukaryotes.

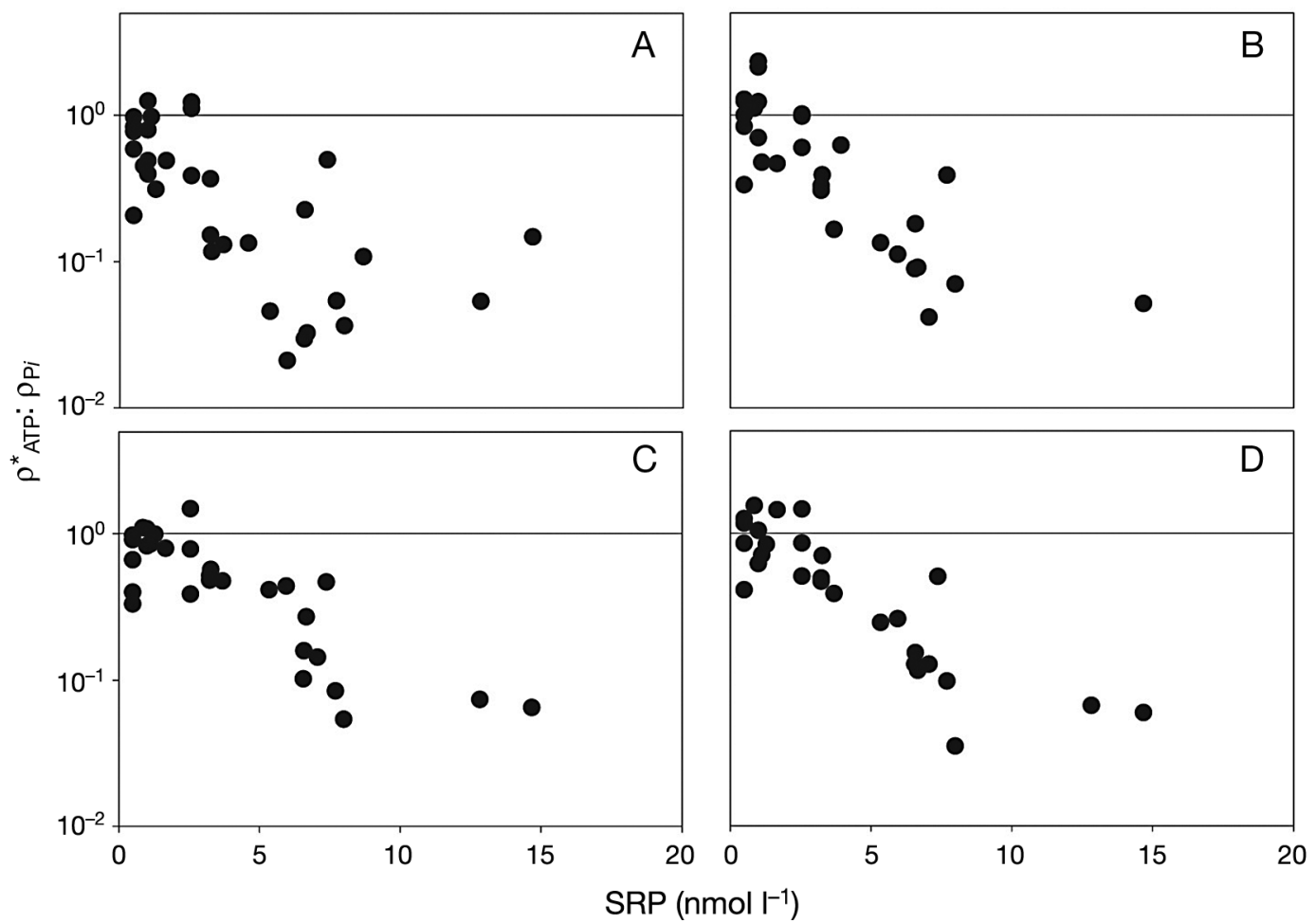

Fig. 7. The assimilated adenosine 5 triphosphate:assimilated orthophosphate $\left(\rho^{*}{ }_{\mathrm{ATP}}: \rho_{\mathrm{P} i}\right)$ ratio for (A) Prochlorococcus, (B) Synechococcus, (C) picoeukaryotes, and (D) nanoeukaryotes plotted as a function of soluble reactive phosphorus (SRP)

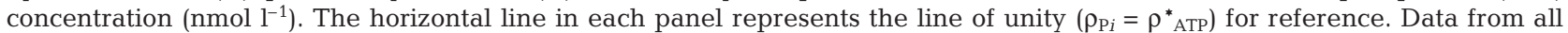

depths and cruises are included

\section{Ecological implications}

From cell-specific utilization rates, we were able to calculate P-specific physiological growth rates, assuming that tracer remineralization is negligible and $\mathrm{P}$ utilization rates are tightly coupled to growth rates in Plimited regions. $\mathrm{P}$ quotas of the Prochlorococcus strain MED4 (0.34 \pm 0.08 fg P cell ${ }^{-1}$; Bertilsson et al. 2003) were divided by the sum of the cell specific $\rho_{\mathrm{P} i}$ and $\rho^{*}$ ATP. With the above caveats, we conservatively estimate growth rates for Prochlorococcus to be $0.59 \pm$ $0.06 \mathrm{~d}^{-1}$ (X0705) and $0.71 \pm 0.09 \mathrm{~d}^{-1}$ (BVal39), which are not significantly different $(p=0.891)$. These growth rate estimates are similar to previous estimates of $0.42 \pm 0.17 \mathrm{~d}^{-1}$ using a similar flow cytometric-stable isotope protocol based on nitrogen utilization rates in the Sargasso Sea (Casey et al. 2007). These are well within the range of other growth rate estimates for Prochlorococcus in the subtropical North Atlantic; for example, growth rates estimated from chl a pigmentlabeling techniques range from 0.1 to $0.5 \mathrm{~d}^{-1}$ (Goericke 1998), C:chl a ratios give a range of from 0.6 to $0.9 \mathrm{~d}^{-1}$ (Malone et al. 1993), in situ growth rates range from 0.7 to $1.4 \mathrm{~d}^{-1}$ (Furnas \& Crosbie 1999), and dilution techniques yield a range of from 0.1 to $1.3 \mathrm{~d}^{-1}$ (Lessard \& Murrell 1998, Stelfox-Widdicombe et al. 2000, Quevedo \& Anadon 2001). Assuming a P quota of $0.81 \pm$ 
0.01 fg P cell ${ }^{-1}$ for Synechococcus (Bertilsson et al. 2003), we estimate Synechococcus growth rates to be $0.48 \pm 0.04 \mathrm{~d}^{-1}$ (X0705) and $1.14 \pm 0.12 \mathrm{~d}^{-1}$ (BVal39). Log-normalized growth rates for Synechococcus were significantly higher for BVal39 than for X0705 ( $p<$ 0.05), and Synechococcus growth rates during BVal39 were significantly higher than those for Prochlorococcus ( $\mathrm{p}<0.001)$. Growth rates derived from P-utilization rates for Synechococcus were within the range of in situ growth rates $\left(0.7\right.$ to $2.1 \mathrm{~d}^{-1}$; Furnas \& Crosbie 1999), but higher than dilution experiment growth rates (0.37 to $0.67 \mathrm{~d}^{-1}$; Worden \& Binder 2003). Unfortunately, due to the diversity of populations within the operational categories of pico- and nanoeukaryotes, and the lack of cell quota data, we cannot make the same calculations for the eukaryotic groups.

Collectively, these data suggest that, to satisfy the cellular P quota, phytoplankton can and do utilize both dissolved inorganic and organic sources depending on the availability of the former. It is worth noting, however, that bacterivory may also be a mechanism of $\mathrm{P}$ acquisition (Zubkov \& Tarran 2008). When SRP is exhausted, growth rates must be limited exclusively to utilization of $\mathrm{P}$ substrates. We propose that the rate at which SRP is exhausted may be primarily influenced by the relative proportions of phytoplankton species efficient in the utilization of Pi. Following this logic, the subsequent species composition would be driven at least partially by the efficiency of DOP hydrolysis and utilization. We speculate that due to variability in $\rho^{*}$ ATP and $\rho_{\mathrm{P} i}$ between phytoplankton groups, seasonal changes in the phytoplankton community structure will greatly affect the composition of the dissolved $\mathrm{P}$ pool.

Acknowledgements. We thank the BATS technicians and members of the $\mathrm{ATP}^{3}$ project who assisted in the collection of the samples presented in the present paper, and R. Condon for valuable comments and discussions. This research was supported by the NSF Biological Oceanography Program through awards OCE-0453023 (M.W.L.), OCE-0451419 (S.T.D.), and OCE-0452904 (J.W.A.). V.M. was supported by a Microbial Observatory award (MCB-0453993). We also acknowledge support for the Bermuda Atlantic Time-Series Study provided by the NSF Chemical and Biological Oceanography Programs through award OCE-0326885, and Major Research Instrumentation (MRI) program award DBI0420821. This is BIOS Contribution Number 1715.

\section{LITERATURE CITED}

Ammerman JW, Glover WB (2000) Continuous underway measurements of microbial ectoenzyme activities in aquatic ecosystems. Mar Ecol Prog Ser 201:1-12

Ammerman JW, Hood RR, Case D, Cotner JB (2003) Phosphorus deficiency in the Atlantic: an emerging paradigm in oceanography. EOS Trans Am Geophys Union 84:165-170
Azam F, Hodson R (1977) Dissolved ATP in seawater and its utilization by marine bacteria. Nature 267:696-698

Bertilsson S, Berglund O, Karl DM, Chisholm SW (2003) Elemental composition of marine Prochlorococcus and Synechococcus: implications for the ecological stoichiometry of the sea. Limnol Oceanogr 48:1721-1731

Bouman HA, Ulloa O, Scanlan DJ, Zwirglmaier K and others (2006) Oceanographic basis of the global surface distribution of Prochlorococcus ecotypes. Science 312:918-921

Casey J, Lomas MW, Mandecki J, Walker D (2007) Prochlorococcus contributes to new production in the Sargasso Sea deep chlorophyll maximum. Geophys Res Lett 34, L10604, doi:10.1029/2006GL028725

Cavender-Bares KK, Karl DM, Chisholm SW (2001) Nutrient gradients in the western North Atlantic Ocean: relationship to microbial community structure and comparison to patterns in the Pacific Ocean. Deep-Sea Res I 48: 2373-2395

Cianca A, Helmke P, Mourino B, Rueda MJ, Llinás O, Neuer $\mathrm{S}$ (2007) Decadal analysis of hydrography and in situ nutrient budgets in the western and eastern North Atlantic subtropical gyre. J Geophys Res 112, CO7025, doi: 10.1029/ 2006JC003788

Donald KM, Joint I, Rees A, Woodward EMS, Savidge G (2001) Uptake of carbon, nitrogen and phosphorus by phytoplankton along the $20^{\circ} \mathrm{W}$ meridian in the NE Atlantic between $57.5^{\circ} \mathrm{N}$ and $37^{\circ} \mathrm{N}$. Deep-Sea Res II 48 : 873-897

DuRand M, Olson R, Chisholm S (2001) Phytoplankton population dynamics at the Bermuda Atlantic time-series station in the Sargasso Sea. Deep-Sea Res II 48:1983-2003

> Dyhrman ST, Palenik B (1999) Phosphate stress in cultures and field populations of the dinoflagellate Prorocentrum minimum detected by a single-cell alkaline phosphatase assay. Appl Environ Microbiol 65:3205-3212

Dyhrman ST, Ruttenberg K (2006) Presence and regulation of alkaline phosphatase activity in eukaryotic phytoplankton from the coastal ocean: implications for dissolved organic phosphorus remuneration. Limnol Oceanogr 51: 1381-1390

Dyhrman S, Webb E, Anderson DM, Moffett JW, Waterbury JB (2002) Cell-specific detection of phosphorus stress in Trichodesmium from the western North Atlantic. Limnol Oceanogr 47:1832-1836

> Fu F, Zhang Y, Bell P, Dutchins D (2005) Phosphate uptake and growth kinetics of Trichodesmium (Cyanobacteria) isolates from the North Atlantic Ocean and the Great Barrier Reef, Australia. J Phycol 41:62-73

Furnas MJ, Crosbie ND (1999) In situ growth dynamics of photosynthetic prokaryotic picoplankters Synechococcus and Prochlorococcus. In: Charpy L, Larkum AWD (eds) Marine cyanobacteria. Bulletin de l'Institut Oceanographique, Monaco, Special 19, p 387-417

Goericke R (1998) Response of phytoplankton community structure and taxon specific growth rates to seasonally varying physical forcing in the Sargasso Sea off Bermuda. Limnol Oceanogr 43:921-935

Heldal M, Scanlan D, Norland S, Thingstad T, Mann N (2003) Elemental composition of single cells of various strains of marine Prochlorococcus and Synechococcus using X-ray microanalysis. Limnol Oceanogr 48:1732-1743

Ho T, Quigg A, Finkel Z, Milligan AJ, Wyman K, Falkowski P, Morel FMM (2003) The elemental composition of some marine phytoplankton. J Phycol 39:1145-1159

Ikeya T, Ohki K, Takahashi M, Fujita Y (1997) Study on phosphate uptake of the marine cyanophyte Synechococcus sp. NIBB 1071 in relation to oligotrophic environments in the 
open ocean. Mar Biol 129:195-202

Karl DM, Bossard P (1985) Measurement and significance of ATP and adenine nucleotide pool turnover in microbial cells and environmental samples. J Microbiol Methods 3: 125-139

Karl DM, Tien G (1992) MAGIC: a sensitive and precise method for measuring dissolved phosphorus in aquatic environments. Limnol Oceanogr 37:105-116

Knap A, Michaels A, Steinberg D, Bahr F and others (1997) BATS methods manual, Ver 4. U.S. JGOFS Planning Office, Woods Hole, MA

Kobori H, Taga N (1979) Phosphatase activity and its role in the mineralization of organic phosphorus in coastal sea water. J Exp Biol Ecol 36:23-39

Kolowith L, Ingall E, Benner R (2001) Composition and cycling of marine organic phosphorus. Limnol Oceanogr 46:309-320

Larsen A, Tanaka T, Zubkov MV, Thingstad TF (2008) P-affinity measurements of specific osmotroph populations using cell-sorting flow cytometry. Limnol Oceanogr Methods 6:355-363

Lessard EJ, Murrell MC (1998) Microzooplankton herbivory and phytoplankton growth in the northwestern Sargasso Sea. Aquat Microb Ecol 16:173-188

Li WKW (1994) Primary production of prochlorophytes, cyanobacteria, and eukaryotic ultraphytoplanktonMeasurements from flow cytometric sorting. Limnol Oceanogr 39:169-175

Lomas MW, Swain A, Shelton R, Ammerman JW (2004) Taxonomic variability of phosphorus stress in Sargasso Sea phytoplankton. Limnol Oceanogr 49:2303-2310

Lovdal T, Tanaka A, Thingstad F (2007) Algal-bacterial competition for phosphorus from dissolved DNA, ATP, and orthophosphate in a mesocosm experiment. Limnol Oceanogr 52:1407-1419

Malone T, Pike S, Conley D (1993) Transient variations in phytoplankton productivity at the JGOFS Bermuda TimeSeries Station. Deep-Sea Res I 40:903-924

Martiny AC, Coleman ML, Chisholm SW (2006) Phosphate acquisition genes in Prochlorococcus ecotypes: evidence for genome-wide adaptation. Proc Natl Acad Sci USA 103:12552-12557

> Martiny AC, Huang Y, Li W (2009) Occurrence of phosphate acquisition genes in Prochlorococcus cells from different ocean regions. Environ Microbiol 11:1340-1347

Mather R, Reynolds S, Wolff G, Williams RG and others (2008) Phosphorus cycling in the North and South Atlantic Ocean subtropical gyres. Nature Geosciences 1:439-443

Moore LR, Ostrowski M, Scanlan DJ, Feren K, Sweetsir T (2005) Ecotypic variation in phosphorus-acquisition mech-

Editorial responsibility: Daniel Vaulot, Roscoff, France anisms within marine picocyanobacteria. Aquat Microb Ecol 39:257-269

Moutin T, Thingstad T, Wambeke F, Marie D, Slawyk G, Raimbault P, Claustre H (2002) Does competition for nanomolar phosphate supply explain the predominance of the cyanobacterium Synechococcus? Limnol Oceanogr 47 : 1562-1567

> Neuer S, Davenport B, Freudenthal T, Wefer G and others (2002) Differences in the biological carbon pump at three subtropical ocean sites. Geophys Res Lett 29, 1885, doi:10.1029/2002GL015393

Not F, Gausling R, Azam F, Heidelberg J, Worden AZ (2007) Vertical distribution of picoeukaryotic diversity in the Sargasso Sea. Environ Microbiol 9:1233-1252

Quevedo M, Anadón R (2001) Protist control of phytoplankton growth in the subtropical north-east Atlantic. Mar Ecol Prog Ser 221:29-38

Quinn G, Keough M (2002) Experimental design and data analysis for biologists. Cambridge University Press, New York

Ridal J, Moore R (1990) A re-examination of the measurement of dissolved organic phosphorus in seawater. Mar Chem 29:19-31

Solorzano L, Sharp JH (1980) Determination of total dissolved phosphorus and particulate phosphorus in natural waters. Limnol Oceanogr 25:754-758

Stelfox-Widdicombe CE, Edwards ES, Burkill PH, Sleigh MA (2000) Microzooplankton grazing activity in the temperate and sub-tropical NE Atlantic: summer 1996. Mar Ecol Prog Ser 208:1-12

Taft J, Loftus M, Taylor W (1977) Phosphate uptake from phosphomonoesters by phytoplankton in Chesapeake Bay. Limnol Oceanogr 22:1012-1021

> Van Mooy BAS, Fredricks HF, Pedler BE, Dyhrman ST and others (2009) Phytoplankton in the ocean use nonphosphorus lipids in response to phosphorus scarcity. Nature 458:69-72

> Worden AZ, Binder BJ (2003) Application of dilution experiments for measuring growth and mortality rates among Prochlorococcus and Synechococcus populations in oligotrophic environments. Aquat Microb Ecol 30:159-174

Wu J, Sunda W, Boyle E, Karl D (2000) Phosphate depletion in the western North Atlantic Ocean. Science 289:759-762

Zubkov MV, Tarran GA (2008) High bacterivory by the smallest phytoplankton in the North Atlantic Ocean. Nature 455:224-226

Zubkov MV, Mary I, Woodward E, Warwick P, Fuchs B, Scanlan D, Burkill P (2007) Microbial control of phosphate in the nutrient-depleted North Atlantic subtropical gyre. Environ Microbiol 9:2079-2089

Submitted: March 2, 2009; Accepted: July 6, 2009

Proofs received from author(s): October 1, 2009 